\title{
Inventar personajes y alejarse de la trama: Entrevista a Ximena Escalante
}

\section{Rocío Galicia}

Ximena Escalante estudió en el Centro Universitario de Teatro de la UNAM y la Escuela de Escritores de México. Sus maestros fueron Hugo Argüelles, Ludwik Margules y Juan José Gurrola. En España se licenció en Ciencias Teatrales en la Real Escuela Superior de Arte Dramático, institución donde fue alumna de Luis Alonso de Santos. Posteriormente hizo el doctorado en Historia del Arte en la Universidad Complutense. Ximena Escalante es una dramaturga mexicana que desde su irrupción en la escena en 2002 con Fedra y otras griegas acaparó la atención de la crítica y el público. Su madurez creativa aunada a un conocimiento profundo de la literatura dramática y la teatralidad le permitieron de inmediato destacar como autora, crítica y formadora de dramaturgos y cineastas. Con tres y hasta cuatro montajes por año - con localidades agotadas - Ximena Escalante se ha convertido en una de las dramaturgas predilectas del público mexicano. Si pretendiéramos definir en pocas palabras su obra destacaríamos su apuesta por el lenguaje, la recurrencia a los personajes míticos, la exploración del universo femenino y una compleja propuesta a nivel estructural.

Álvaro Custodio, tu abuelo, fue un importante promotor y director español exiliado en México, ¿este hecho influyó en tu vida?

Sí, en la casa de mi abuelo se hablaba todo el tiempo de teatro, él fundó la Compañía de Teatro Clásico de México y su esposa era diseñadora de vestuario, en consecuencia todas sus conversaciones giraban en torno a proyectos escénicos. ${ }^{1}$ Hizo mucho teatro clásico, por lo cual los versos de Lope de Vega y Calderón de la Barca resonaban en las paredes de su casa. Yo desde niña quería ser actriz, pero me daba mucha pena actuar. En contraste, me fascinaba contar historias e inventar personajes. Mi primera 
obra de teatro que escribí y se montó la hice a los 15 años, en mi primer taller de dramaturgia con Antonio González Caballero. La obra se llama Las viudas. Recuerdo que mientras tomaba clases con González Caballero leía a Shakespeare. Antonio González Caballero nos pidió que escribiéramos una obra, yo no sabía de qué escribir, entonces leí en el periódico una nota que decía "VIUDAS." A mí esa palabra me cautivó. Pensé: "Puede haber una viuda, ¿pero viudas?" Fue así que escribí mi primera obra de teatro. Eran cinco viudas, cada una tenía un color: viuda negra, blanca, roja, púrpura y rosa. Era una obra muy argüellana. Cuando entré a los 18 años al taller de Hugo Argüelles me di cuenta que era una obra cercana a su estilo. Las viudas fue dirigida por Guillermo Caballero. Yo actuaba en la obra, era la Viuda Púrpura. Después de las clases con Argüelles ingresé al diplomado de la Escuela de la Sociedad de Escritores de México, posteriormente me fui a estudiar a España.

\section{¿Qué experiencia reconoces como nuclear para tu escritura?}

La formación que tuve en España. No se enseña a escribir, pero sí tuve un soporte teórico muy importante, además de experiencias de vida y viajes que me nutrieron. Nadie me enseñó a escribir estrictamente hablando, pero sí conocí a muchos escritores, los leí, me enamoré de sus obras y las estudié a fondo. Hice mi tesis sobre Pirandello y escribí una obra que se llama La siesta de Pirandello.

Regresas a México en 1997 y escribes Fedra y otras griegas, Yo también quiero un profeta (sobre Salomé), Colette (escritora francesa llamada la "Fedra del siglo XX"), Andrómaca Real y Unos cuántos piquetitos (a partir de Frida Kalho), ¿por qué la necesidad de volver a estos personajes míticos?

A mí me interesa romper con los mitos. Yo de niña tuve una formación de mucha exigencia por parte de mis abuelos y de mi mamá. Ella me obligaba a leer varias horas al día. En cada mano se colocaba libros que me mostraba y me decía: "O lees sobre Grecia o sobre Egipto." Egipto me aburrió muchísimo y en cambió la mitología griega me fascinó. Entre los 11 y los 15 años aprendí mucho de mitología. Había un libro en especial que me encantaba porque reunía imágenes que se habían pintado sobre Atenea, Morfeo o sobre el rapto de Eurídice. A mí esas imágenes me suscitaban preguntas. Pensaba: “¿Por qué pintaron precisamente este momento? ¿Por qué no captaron a los personajes antes o después?” De ahí salió mi inquietud de escribir las cosas 
que no estaban contadas, pero para eso hay que hacer un trabajo exhaustivo de investigación, el cual en mi opinión está íntimamente relacionado con la escritura. Yo creo que la escritura es investigación y recreación.

Para ti el proceso de investigación es sumamente placentero, ¿estoy en lo cierto?

Sí, me encanta. Cuando descubro algo que me apasiona lo disfruto intensamente. Para escribir Fedra y otras griegas no puedes imaginarte la cantidad de Fedras que leí, lo mismo me pasó con el personaje de Salomé. El proceso de creación de Colette me llevó hasta la casa de esta escritora en Francia. La investigación de Unos cuantos piquetitos implicó la revisión de pinturas de Frida Kalho y la obtención de testimonios de personas que la conocieron. La Frida fue interesante porque la obra partió de un cuadro, el más insignificante y feo de Frida, pero lo elegí porque me detonaba una historia muy fuerte.

En otro lugar dijiste: "Hacer teatro es hacer poesía."

El teatro, en comparación con el cine o la televisión, sigue siendo poesía, sigue siendo la búsqueda de belleza en la palabra. No podemos competir

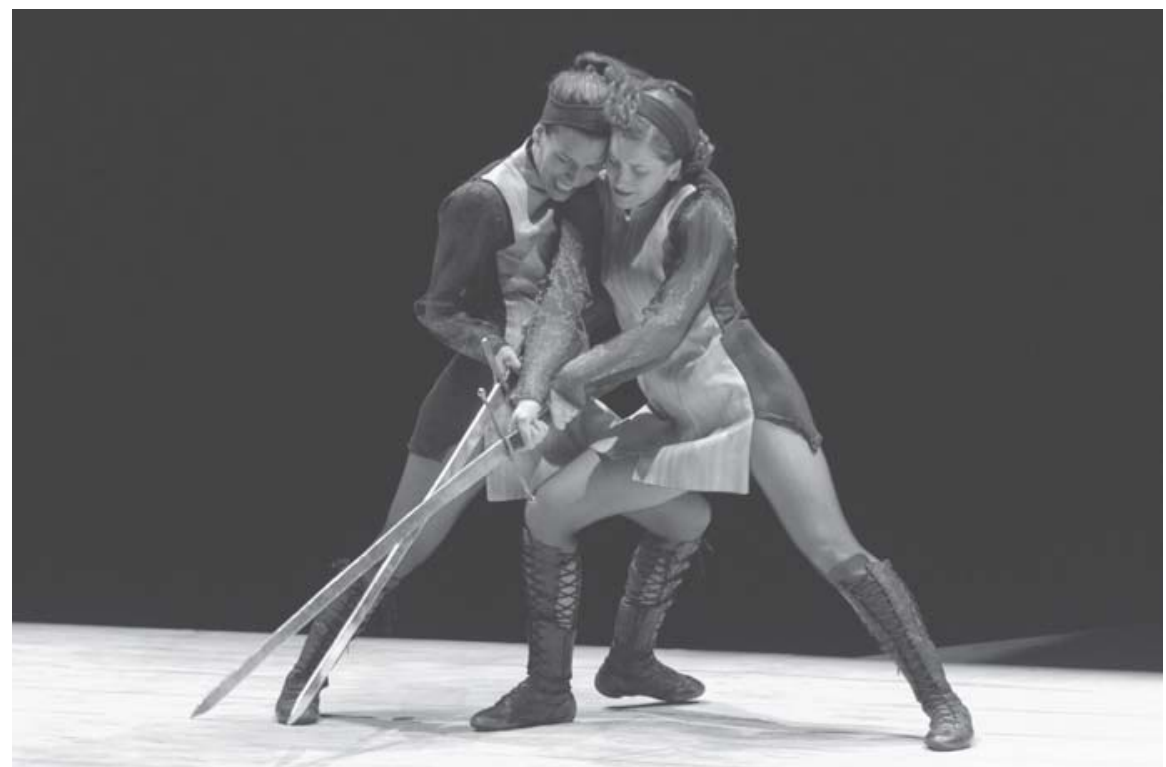

Toché o la crótica del combate. Foto: Christa Cowrie. Archivo del CIRTU 
con la trama o con el poder de contar historias o problemas de los seres humanos que tiene el cine. El cine es un lenguaje, el teatro es otro. En el teatro es fundamental la búsqueda de una poética, no sólo en el texto, sino en la escenificación. El teatro se despega del realismo, el teatro tiene un poder de abstracción y de evocación, un poder de detonar la subjetividad del espectador que no tienen ni el cine ni la televisión. Esto lo logra el teatro a través de la palabra, la palabra es una especie de embrujo.

Eres una dramaturga en constante proceso de cambio, tienes obras que se han sostenido en la investigación textual, otra línea la ha constituido el trabajo de campo y una tercera ha sido la relación directa con los actores y el escenario.

Sí, cada obra es diferente, por ejemplo en el caso de Touché o la erótica del combate los actores venían de un grupo que practica el combate escénico y querían una obra que se llamara Touché. A mí me encantó la idea. Me mostraron unas improvisaciones que tenían, pero no me provocaban, así que les propuse entrevistarlos y de su propia vida generar el material dramático. Los entrevisté durante meses, con base en ese material fui creando los personajes, luego escenas y situaciones. Un día elaboré la posible trama, pero trabajando con ellos reafirmé que la trama a mí ya no me importa. Cuanto más me he ido alejando de la trama he ido entendiendo el gran poder de la ficción. Me interesa más trabajar los personajes, o la palabra o los momentos.

Andrómaca Real es una propuesta dramática que se abre al espectador...

Sí, es una obra que me gusta mucho, de hecho la sigo reescribiendo. A mí me gusta porque tiene dos trayectorias: la realidad y el sueño que va en sentido contrario, pero es lo mismo. En Andrómaca Real había muchas posibilidades de tiempo, espacios, reencuentros y desencuentros, finalmente decidí trabajar solamente con la vida real y la vida soñada, pero es un sueño donde todos los personajes sueñan y están metidos en el sueño de Orestes. Todos están soñando o soñaron algo parecido. En esta obra descubrí posibilidades. En el momento en que entré en el territorio del sueño se me abrió un mundo. A partir de ahí escribí Judith que es una obra que ocurre en la mente de un personaje, no es una historia que acontece, es una historia que se está imaginando alguien en un momento. Touché es la última obra donde hablo de amor. 


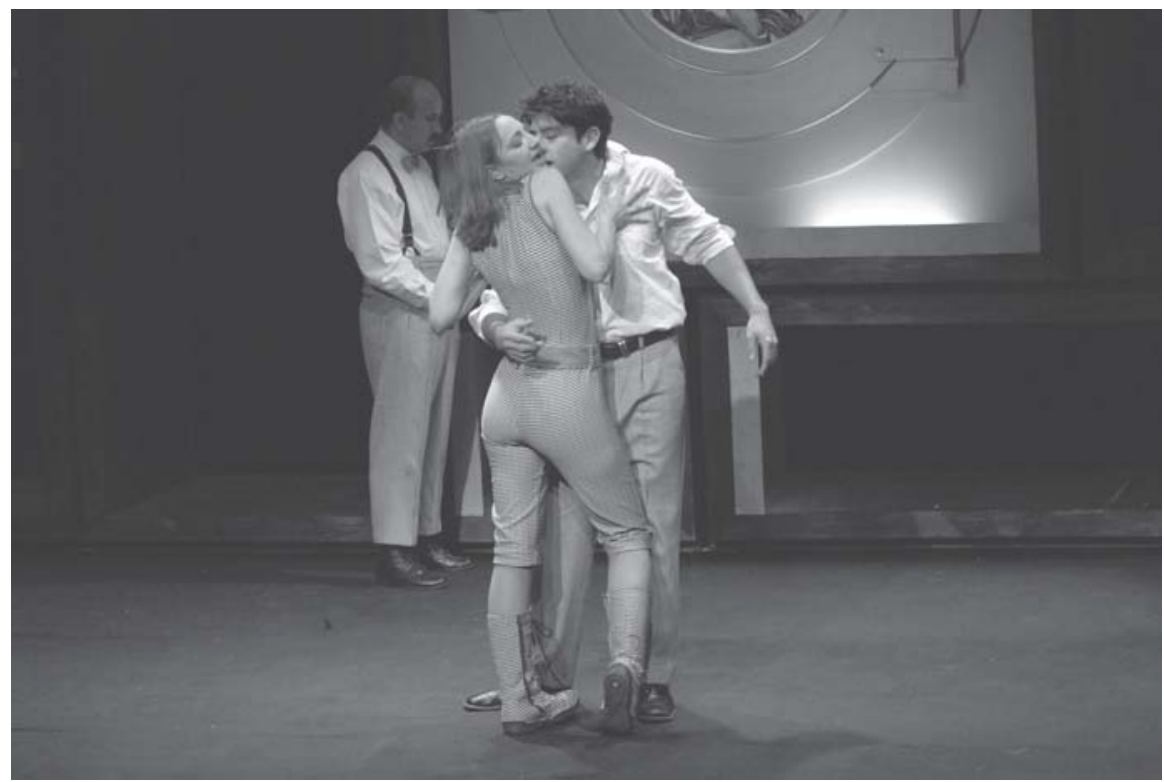

Andrómaca Real. Foto: Christa Cowrie. Archivo del CIRTU

¿A qué atribuyes el éxito de tus obras?

Me preocupo por el público. El teatro no se hace para cinco amigos ni para todo el mundo. El teatro es cada vez un espacio de ciertas personas, pero sí me importa llegar a esas personas y no nada más a mis hermanos, primos, hijos y colegas. He querido decir algo que exprese el sentir de este momento, el sentir de las personas, de esta vida, de este mundo.

¿Cómo han recibido tus obras en el extranjero?

Muy bien. Fedra y otras griegas, por ejemplo se ha publicado en inglés, italiano, alemán y tiene dos traducciones al francés, una se hizo en Francia y otra en Québec. Fedra se produjo en Francia con una compañía profesional que ha dado funciones en todo el mundo. Tengo una obra que se presenta desde hace, siete años, se llama Clown Quijote de la Mancha, es una obra para niños. Yo también quiero un profeta fue traducida al francés y al inglés y se ha presentado en Nueva York y Canadá. Unos cuantos piquetitos tuvo una gira por Europa. Me ha ido bien. Me podría ir mejor si yo misma procurara mis obras, pero no lo hago. 
¿Cuáles de tus obras han resultado polémicas?

Yo también quiero un profeta porque había mucha violencia. El público protestaba, había opiniones divididas, algunos preguntaban para qué tanta violencia y, por otro lado, estaban quienes quedaban enamorados de la obra y la violencia. La piel fue una propuesta en sentido contrario, era extremadamente suave, nunca había un conflicto poderoso, dramático. Algunos decían: "Estábamos esperando una obra fuerte, violenta." Esas obras fueron muy distintas en todo, en la temática, en los personajes, en la estructura. El público esperaba a una dramaturga que va en una misma dirección. No puedo, ha sido muy difícil porque las obras han tenido teatro lleno, en tanto, la crítica ha sido fuerte. Pero ya no me importa.

¿Has tenido problemas de censura?

En teatro no, sí en televisión y cine.

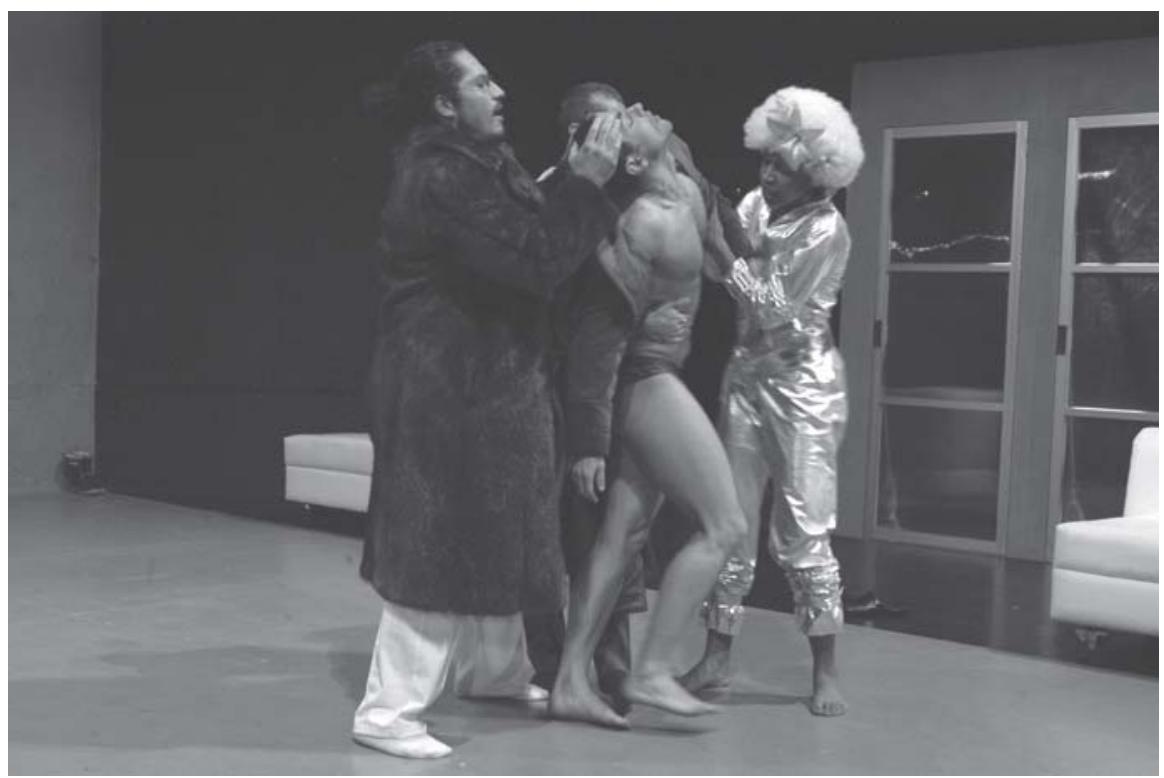

La piel. Foto: Christa Cowrie. Archivo del CIRTU

¿Tienes a priori la preocupación de plasmar feminidad en un contexto mexicano donde la voz abrumadoramente ha sido masculina?

No. Y ahora estoy en un momento en que ya me aburrí de mí misma. Veo mis obras y me dan una flojera espeluznante, ya no me aguanto. Tengo mucho miedo de esta etapa. 
Qué significativas son estas palabras cuando eres una dramaturga exitosa...

Siento que me repito. De Touché me gustó mucho el proceso, fue muy interesante, me llenó, pero ya no quiero escribir más de amor. Ya me hartaron las relaciones amorosas.

¿Crees que la crítica masculina no se ha permitido entrar a los universos que propones?

He oído de muchos hombres que sienten que mis personajes masculinos no son tan sólidos como los femeninos, que a veces estoy en contra de los hombres, pero tal vez es un accidente de mi inconsciente. Sí siento y sí me he identificado como muchas mujeres de mi generación que pensamos en la imposibilidad del amor, de eso han hablado mis obras. Tengo personajes mujeres y hombres que no pueden traspasar sus propias limitaciones.

\section{¿Qué estás escribiendo ahora?}

Estoy haciendo un musical que es el género que me faltaba explorar. Es un musical que tiene que ver con México y con una estética mexicana.

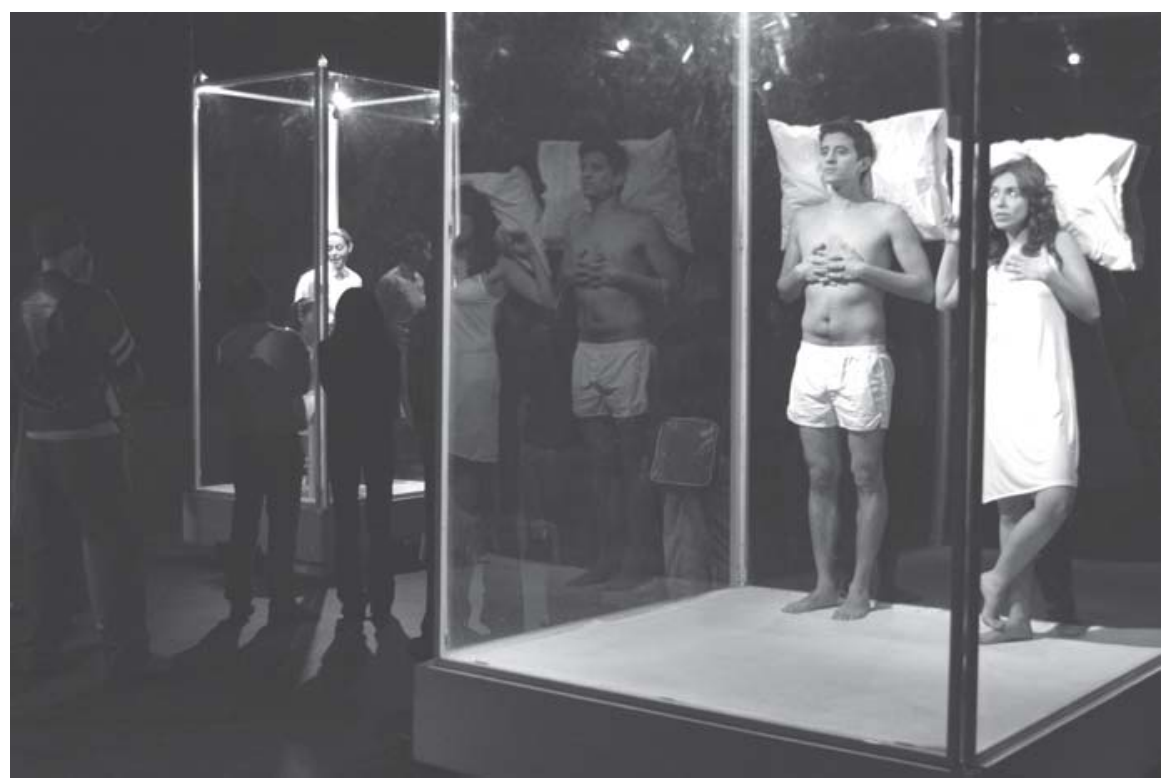

Te odio. Foto: Christa Cowrie. Archivo del CIRTU 
Después quiero seguir indagando sobre ciertos personajes griegos y abordar la vida de algunos escritores. Quiero escribir una obra sobre Tennessee Williams. Sigo interesada más en los personajes que en la historia, cada vez me interesa menos la trama, me interesan los procesos sobre la escena. En mi escritorio escribo televisión que es algo que me encanta y me divierte. Para escribir teatro necesito el escenario, el contacto con la gente y al actor para que me hable de las posibilidades dramáticas.

Centro Nacional de Investigación Teatral "Rodolfo Usigli," México

\section{Nota}

Álvaro Custodio (1914-1992) perteneció al teatro universitario ambulante $L a$ Barraca, fundado por Federico García Lorca. En 1939 Custodio salió de España, se trasladó a Francia y después a Cuba. En 1944 llegó a México como exiliado. En 1953 fundó la compañía Teatro Español de México luego denominada Teatro Clásico de México. También fue dramaturgo, crítico y pionero de las publicaciones teatrales en México. 